five-year course of study (three years for a certificate followed by two further years for a diploma) leading to the associate grade. Information on the aims of the Institute, examination syllabuses and details of membership may be obtained from the registered office of the Institute: Hon. General Secretary, F. W. L. Croker, Chemistry Department, Imperial College of Science and Technology, London, S.W.7.

\section{Engineering Appointments in Great Britain during} 1954

DURINa 1954 the Professional Engineers Appointments Bureau (9 Victoria Street, London, S.W.1) submitted particulars of more than nine thousand engineers for vacancies notified in civil, mechanical and electrical engineering, and this is the highest annual number recorded since the Bureau was set up nine years ago by the Institutions of Civil, of Mechanical and of Electrical Engineers. There has been an increase in the number of registrations with the Bureau, many from overseas, and this increase contributes to the better service which the Bureau can offer to employers. On the other hand, because of the full employnent position, there is a reluctance on the part of many engineers to change their employment unless substantial benefits are likely to result. The main demands in eivil engineering have been for engineers with wide design experience, good contractors' experience and for young engineers prepared to accept overseas posts ; there has also been a big increase in technical vacancies notified by local authorities. In mechanical engineering requirements have been varied and have included posts for engineers with experience in chemical engineering plant, hydraulics, servo-mechanisms, production and management. The major proportion of electrical vacancies have called for experience in the sphere of electronics and light-current engineering, including instruments.

\section{Forestry in Northern Ireland}

IN an introduction to a well-illustrated pamphlet issued by the Minister of Agriculture in Northern Ireland, entitled "Forestry in Northern Ireland" (pp. 20; Belfast, 1954), a brief historical review is given of the forests of the region in the past. It was not until 1903 that a definite step to stop deforestation, which the great storm of that year had increased, was taken. A forestry branch of the Department of Agriculture was inaugurated, technical instruction was undertaken and Avondale in Co. Wicklow was acquired as the first forestry centre and training school. Progress has been made since then. The forest policy laid down is governed by three principal factors. First, there is the compelling need, which two World Wars have demonstrated, to reverse the centuries-old process of deforestation and to create home-grown timber resources equal to emergency requirements. Secondly, it is necessary to provide productive work in areas of serious unemployment; and thirdly, though private planting can contribute usefully, under present economic conditions any such contribution must be small. A Forestry Act (Northern Ireland) was passed in 1953, and afforestation and other work is proceeding under the Act. As in so much of Britain, sitka spruce is the most important single species in the reafforestation programme.

\section{The German Plastics Industry}

THE German Forschungsgesellschaft Kunststoffe e.V., a union of 189 firms, was founded in 1953 with the object of promoting the scientific investigation and practical application of plastics (Kunststoffe) and the development of the industry. It has founded the Deutsche Kunststoff-Institut in Darmstadt, under the direction of Prof. K. H. Hellwege and in the grounds of the Technical Institute, and the new Institute is expected to be functioning fully at the end of 1956. It will comprise laboratories and workshops, a library and documentary department, and a separate hall of manufacture equipped with all the necessary machinery. The staff will comprise eight to ten physicists, chemists and engineers. The cost will be largely met by members of the Forschungsgesellsehaft, with assistance from the State of Hesse. The programme of research will be under the direction of a board, including the chairman of the Forschungsgesellschaft, State and town officials, the Rector of the Technical Institute of Darmstadt, and representatives of science and industry. The foundation stone was laid last May, with appropriate ceremonies, in which the Minister of Education participated. A casket containing specimens of various plastics was enclosed in the foundation stone. The organization has recently established a literary service called a Literatur-Schnelldienst, which is available to members and non-members. This is planned to appear monthly and takes the form of a prompt documentation by titles and short abstracts of all publications and patents, both German and foreign, of interest in all branches of the science and technology of plastics. This publication, a specimen of which in the form of photostat copies of sheets has been received at the office of Nature, is apparently issued by the Arbeitsgemeinschaft Deutsche Kunstoff-Industrie, 4 Güterplatz, Frankfurt-am-Main 1, the director being Dr. H. Saechtling. The price of the Literatur-Schnelldienst is given as $80 \mathrm{DM}$. to members of the Forschungsgesellschaft and $200 \mathrm{DM}$. to non-members per annum.

\section{Announcements}

THE Wellcome Trustees announce that, with the approval of the chairman of the Medical Research Council, they have appointed Brigadier J. S. K. Boyd to be a Trustee as from January 1, 1956, in succession to Prof. T. R. Elliott, who is retiring from the trusteeship in October. Brigadier Boyd is relinquishing the directorship of the Wellcome Laboratories of Tropical Medicine on December 31, and will be succeeded by Dr. R. S. F. Hennessey, who, until his recent retirement, was director of medical services, Uganda.

THE following lecturers in the University of Aberdeen have been appointed readers in the subjects stated, as from October 1: Dr. H. W. Kosterlitz (physiology); Dr. T. N. Morgan (materia medica); Dr. W. P. D. Wightman (history and philosophy of science); Dr. W. T. H. Williamson (soil science).

THe French Society of Metallurgy is holding its annual "Journées Métallurgiques d'Automne" in Paris during October 24-29. Further information can be obtained from the Société Française de Métallurgie, 25 rue de Clichy, Paris 9e.

THE Scottish Group of the Nutrition Society is holding a symposium in Aberdeen on September 17 on "Cholesterol and Fat Metabolism in Relation to Diet and Disease". Both the biochemical and clinical aspects of the subject will be considered. Further particulars can be obtained from Dr. A. M. Thomson, Department of Midwifery, University Medical School, Foresterhill, Aberdeen. 